\title{
Peningkatan Hasil Belajar Kimia Pada Sel Elektrokimia Melalui Model Discovery Learning
}

\author{
Sulistyaningsih ${ }^{(1)}$ \\ ${ }^{1}$ SMKN 01 Blitar \\ Email: ${ }^{1}$ listyonosalim@gmail.com \\ DOI:http://doi.org/10.28926/riset_konseptual.v2i4.117
}

\begin{abstract}
ABSTRAK
Rendahnya prestasi belajar kimia siswa kelas X TITL 2 SMKN 1 Blitar ditunjukan nilai $P$ dan $\mathrm{K}$ pada materi redoks yang belum mencapai batas ketuntasan secara klasikal sebesar $85 \%$. Hal ini terutama disebabkan karena model pembelajaran yang digunakan kurang jelas. Kurikulum 2013 mengamanatkan model Discovery Learning merupakan salah satu model pembelajaran yang sesuai. Penelitian ini menggunakan rancangan Penelitian Tindakan Kelas dengan 2 siklus. Hasil penelitian menunjukan bahwa penerapan model Discovery Learning dapat meningkatkan hasil belajar kimia pada sel elektrokimia siswa kelas X TITL 2 SMKN 1 Blitar dan tercapainya ketuntasan belajar klasikal.
\end{abstract}

\section{Kata kunci: discovery Learning, hasil belajar, kimia}

\section{PENDAHULUAN}

Pelajaran kimia di kelas X TITL 2 SMKN 1 Blitar kurang diminati siswa, karena dianggap sulit dan susah dimengerti. Hal ini ditunjukan dengan rendahnya nilai kimia siswa pada materi redoks yang mendasari materi sel Elektrokimia, dimana jumlah siswa yang mencapai nilai minimal KKM pada aspek pengetahuan sebesar 51,43\% dan aspek ketrampilan sebesar $57,14 \%$ sehingga belum mencapai kriteria kentuntasan belajar secara klasikal sebesar $85 \%$. Rendahnya prestasi siwa kelas X TITL 2 SMKN 1 Blitar dalam pelajaran kimia tersebut menjadi bahan introspeksi peneliti selaku guru kimia di kelas tersebut untuk melakukan suatu tindakan pembelajaran yang mampu memotivasi siswa untuk belajar kimia secara aktif kreatif, dan bermakna.

Proses pembelajaran dapat dipadankan sebagai suatu proses ilmiah, sehingga Kurikulum 2013 mengamanatkan esensi pendekatan saintifik dalam pembelajaran. Melalui pendekatan saintifik diharapkan sebagai sarana yang bagus untuk perkembangan dan pengembangan sikap, ketrampilan dan pengetahuan peserta didik. Salah satu model pembelajaran yang sesuai dengan pendekatan saintifik adalah model Discovery Learning. Penggunaan Discovery Learning, ingin merubah kondisi belajar yang pasif menjadi aktif dan kreatif. Mengubah pembelajaran yang teacher oriented ke student oriented. Merubah modus Ekspository siswa hanya menerima informasi secara keseluruhan dari guru ke modus Discovery siswa menemukan informasi sendiri (Kemendikbud, 2014). Selain itu dari hasil penelitian Enik Wijayanti, S.Pd disimpulkan bahwa penerapan metode discovery terpimpin dapat meningkatkan motivasi dan prestasi belajar siswa kelas X MIA 6 SMA Nahdlatul Ulama 1 Gresik tahun pelajaran 2014/2015 pada pelajaran kimia tentang senyawa hidrokarbon. Hal ini dapat dilihat dari hasil evaluasi yang meningkat (Wijayati: 2016).

Berdasarkan uraian tentang pendekatan pembelajaran kontekstual model Discovery Learning dan temuan-temuan yang dihasilkan dalam proses pembelajaran kimia di kelas $\mathrm{X}$ TITL 2 SMKN 1 Blitar, maka penulis tertarik untuk melakukan penelitian dengan judul " Peningkatan Hasil Belajar Kimia Pada Sel Elektrokimia Melalui Model Discovery Learning di Kelas XTITL 2 SMKN 1 Blitar".

Masalah yang akan dicari penyelesaiannya dalam penelitian ini dapat dirumuskan sebagai berikut: (1) bagaimanakah penerapan model Discovery Learning pada siswa kelas X TITL2 
SMKN 1 Blitar ?, (2) apakah ada peningkatan hasil belajar kimia siswa pada sel elektrokimia setelah diterapkan model Discovery Learning di kelas X TITL2 SMKN1 Blitar ? Sedangkan tujuan yang ingin dicapai dalam penelitian ini yaitu : (1) mendiskripsikan penerapan model Discovery Learning pada siswa kelas X TITL2 SMKN 1 Blitar, (2) mendiskripsikan peningkatan hasil belajar kimia siswa pada sel elektrokimia setelah diterapkan model Discovery Learning di kelas X TITL2 SMKN1 Blitar.

Penelitian ini diharapkan dapat memberikan manfaat antara lain berupa : (1) digunakan sebagai landasan dalam pembenahan proses pembelajaran yang dilakukan di kelas, (2) meningkatkan kemampuan siswa dalam pemahaman dan hasil belajarnya, (3) dijadikan acuan dalam melakukan penelitian sejenis, dan (4) digunakan sekolah sebagai bahan pertimbangan dalam pembuatan kebijakan untuk peningkatan kualitas sekolah.

Pembelajaran kimia pada Kompetensi Keahlian Teknik Instalasi Tenaga Listrik (TITL) sesuai Struktur Kurikulum Pendidikan Menengah Kejuruan yang diputuskan oleh Dirjen Pendidikan Dasar dan Menengah pada tanggal 10 Februari 2017 termasuk kelompok Dasar Bidang Keahlian. Materi kimia yang diajarkan diharapkan mampu membantu siswa dalam memahami materi kelompok kompetensi keahlian (C3) atau praktek kejuruan. Adapun materi sel elektrokimia yang diajarkan di Kompetensi Keahlian Teknik Instalasi Tenaga Listrik (TITL) SMK meliputi sel Volta dan sel elektrolisa.

Alessandro Volta menemukan bahwa pasangan logam tertentu dapat membangkitkan gaya gerak listrik. Gaya gerak listrik inilah yang menyebabkan arus mengalir dalam suatu rangkaian. Arus listrik adalah aliran elektron melalui kawat (Srisumarlinah W, 2016 : hal 8). Pada saat yang sama Luigi Galvani juga menemukan hal yang sama pada reaksi spontan. Rangkaian pasangan logam yang dicelupkan ke dalam larutan elektrolit sehingga menghasilkan arus listrik inilah kemudian yang disebut sebagai sel Volta atau sel Galvani. Sedangkan elektrolisa berasal dari elektro artinya listrik dan analisis berarti uraian. sehingga elektrolisa dapat dikatakan sebagai proses penguraian suatu senyawa kimia melalui reaksi redoks karena adanya arus listrik. Maka pada elektrolisa terjadi perubahan energi dari energi listrik menjadi energi kimia.

Proses pembelajaran dapat dipadankan sebagai suatu proses ilmiah, sehingga Kurikulum 2013 mengamanatkan esensi pendekatan saintifik dalam pembelajaran. Pendekatan saintifik diyakini sebagai titian emas perkembangan dan pengembangan sikap, keterampilan, dan pengetahuan peserta didik. Salah satu model pembelajaran yang sesuai dengan pendekatan saintifik adalah model Discovery Learning. Penggunaan Discovery Learning, ingin merubah kondisi belajar yang pasif menjadi aktif dan kreatif. Mengubah pembelajaran yang teacher oriented ke student oriented. Merubah modus Ekspository siswa hanya menerima informasi secara keseluruhan dari guru ke modus Discovery siswa menemukan informasi sendiri (Kemendikbud, 2014).

Model pembelajaran Discovery Learning diaplikasikan dengan langkah-langkah pembelajaran sebagai berikut: (1) stimulation (pemberian rangsangan), (2) problem statement (identifikasi masalah), (3) data collection (pengumpulan data), (4) data processing (pengolahan data), (5) verivication (pembuktian), dan (6) generalization (menarik kesimpulan). Melalui pembelajaran Discovery Learning ini diharapkan siswa tidak hanya mempelajari apa yang terjadi dalam suatu peristiwa tetapi dapat membelajarkan siswa untuk menemukan penyebab peristiwa itu terjadi serta dampak yang ditimbulkannya, sehingga mampu menumbuhkan sikap ilmiah dan empati pada diri siswa dan pembelajaran menjadi lebih bermakna.

Ilmu kimia berkaitan erat dengan fakta-fakta dan peristiwa yang ada dalam kehidupan sehari-hari. Termasuk fakta-fakta dan peristiwa yang berhubungan dengan kompetensi keahlian teknik instalsi tenaga listrik. Memahami kimia berarti mampu membuat hubungan antar ide, fakta-fakta, dan prosedurnya, pemahaman dalam belajar kimia merupakan suatu proses untuk menempatkan secara tepat informasi atau pengetahuan yang sudah dimiliki sebelumnya di dalam struktur kognitif siswa (Grouws dalam Arends, 2004: 157).

Menurut Permendikbud RI nomor 23 tahun 2016 tentang Standart Penilaian Pendidikan bab I pasal 1 ayat 2 menyatakan penilaian adalah proses pengumpulan dan pengolahan informasi untuk mengukur pencapaian hasil belajar peserta didik. Ada 3 aspek yang diukur untuk menilai kemampuan peserta didik. tiga aspek yang dimaksud adalah : (1) sikap, (2) pengetahuan dan (3) ketrampilan. Dari ketiga aspek penilaian tersebut yang wajib dilaporkan 
JURNAL PENDIDIKAN: Riset dan Konseptual, Vol. 3 No. 2, April 2019 www.journal.unublitar.ac.id/ip E-ISSN: 2598-2877

P-ISSN: 2598-5175

oleh guru kimia adalah penilaian pengetahuan dan ketrampilan. Di dalam mempelajari faktafakta yang ada diperlukan sikap yang baik dari siswa seperti jujur dalam melaporkan pengamatan, rajin dalam melaksanakan tugas dan sebagainya. Maka penilaian terhadap sikap siswa perlu disisipkan dalam fotmat penilaian ketrampilan.

\section{METODE}

Penelitian Tindakan Kelas ini dilaksanakan dalam 2 siklus pada kelas X TITL 2 SMKN 1 Blitar dengan menerapkan model pembelajaran Discovery Learning. Tiap-tiap siklus dilaksanakan 2 kali pertemuan. Dalam penelitian ini menggunakan subyek peneliti selaku guru kimia kelas X TITL 2 SMKN 1 Blitar, beserta seluruh siswa di kelas tersebut yang berjumlah 35 terdiri dari 30 siswa laki-laki dan 5 siswa perempuan.

Rancangan Penelitian Tindakan Kelas (PTK) model Kemmis dan Mc Taggart. Satu kali siklus terdiri dari : planning (perencanaan), acting (tindakan), observing (pengobservasian), dan reflekting ( perefleksian). Hasil dari perefleksian ini selanjutnya digunakan untuk memperbaiki perencanaan (revise plan) berikutnya (Kemmis \& MC.Taggart: 1990 dalam Akbar: 2010).

Dalam penelitian ini menggunakan beberapa instrumen untuk menggambarkan proses dan hasil belajar siswa meliputi : lembar kerja kelompok, rubrik penilaian psikomotor, lembar observasi aktivitas guru, lembar tes tertulis dan catatan lapangan.

Teknik analisis data pada penelitian ini deskriptif secara kualitatif. Data aktivitas guru dari hasil kegiatan observasi dianalisis menggunakan teknik persentase sebagai berikut:

Persentase Nilai Rata-rata (NR) $=\frac{\text { Jumlah Skor }}{\text { Skor Maksimal }} \times 100 \%$
$\begin{array}{ll}\text { Dengan taraf keberhasilan sebagai berikut: } \\ 90 \% \leq N R \leq 100 \% & \text { : Sangat Baik } \\ 80 \% \leq N R<90 \% & \text { : Baik } \\ 70 \% \leq N R<80 \% & \text { : Cukup } \\ 60 \% \leq N R<70 \% & \text { : Kurang } \\ 0 \% \leq N R<60 \% & \text { : Sangat Kurang }\end{array}$

Data hasil belajar siswa dari hasil tes akhir maupun penilaian psikomotor setiap siklus dianalisis dengan menggunakan rumus:

$$
\mathrm{SR}=\frac{\mathrm{S}}{\mathrm{n}} \times 100 \%
$$

Dimana: SR = Persentase skor rata-rata hasil tes siswa atau penilaian psikomotor

$S=$ jumlah siswa yang mendapat skor $\geq 75$

$\mathrm{n}=$ Jumlah siswa

Pembelajaran dikatakan berhasil ( tuntas) jika sekurang-kurangnya $85 \%$ siswa dalam satu kelas telah mencapai nilai minimal KKM yaitu $\geq 75$. Selain itu mengacu pada Panduan Penilaian Hasil Belajar pada Sekolah Menengah Kejuruan yang dikeluarkan Kemendikbud tahun 2017 maka kategori penilaian dengan nilai KKM 75 dan pembulatan angka kesatuan terdekat sebagai berikut:

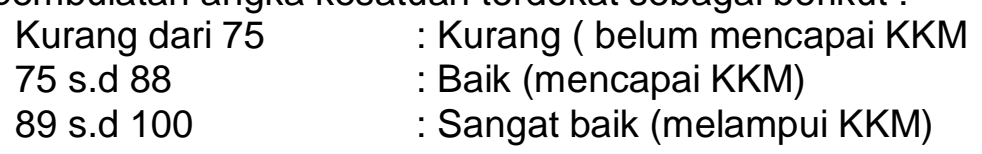


JURNAL PENDIDIKAN: Riset dan Konseptual, Vol. 3 No. 2, April 2019 www.journal.unublitar.ac.id/ip E-ISSN: 2598-2877

P-ISSN: 2598-5175

\section{PEMBAHASAN}

Dari hasil observasi terhadap kegiatan guru dalam penerapan model Discovery Learning pada siswa kelas X TITL2 SMKN 1 Blitar dari siklus I ke siklus II menunjukan guru dapat menerapkan model Discovery Learning dengan baik pada siklus I dengan rata-rata keberhasilan $81,50 \%$. Sedangkan pada siklus II menghasilkan peningkatan sebesar $10,50 \%$ dengan ditunjukan oleh rata-rata keberhasilan sebesar $92,00 \%$ (sangat baik).

Penilaian hasil belajar kimia siswa meliputi aspek ketrampilan dan pengetahuan. Peningkatan hasil belajar kimia siswa kelas X TITL 2 SMKN 1 Blitar aspek ketrampilan dari siklus I ke siklus II menunjukan adanya peningkatan jumlah siswa yang mencapai nilai minimal KKM sebesar 8,58\% (dari 85,71\% menjadi 94,29\%). Dan pada siklus II kategori penilaian terbagi menjadi 5,71\% kategori penilaian kurang, $80 \%$ kategori penilaian baik, dan 14,29\% kategori penilaian sangat baik.

Peningkatan hasil belajar kimia siswa kelas X TITL 2 SMKN 1 Blitar aspek pengetahuan dari siklus I ke siklus II menunjukan adanya peningkatan jumlah siswa yang mencapai nilai minimal KKM sebesar $11,43 \%$ (dari $80,00 \%$ menjadi $91,43 \%$ ). Dan pada siklus II kategori penilaian terbagi $8,57 \%$ kategori penilaian kurang, $82,86 \%$ kategori penilaian baik, dan $8,57 \%$ kategori penilaian sangat baik.

Dari hasil pembahasan di atas jelaslah bahwa hasil belajar kimia pada sel elektrokimia siswa kelas X TITL 2 SMKN 1 Blitar dapat ditingkatkan melalui penerapan model Discovery Learning.

\section{KESIMPULAN}

Dari hasil pembahasan di atas maka dapat disimpulkan : (1) model Discovery Learning dapat diterapkan pada pembelajaran kimia siswa pada sel elektrokimia kelas $X$ TITL2 SMKN 1 Blitar, (2) hasil belajar kimia siswa pada sel elektrokimia kelas $X$ TITL2 SMKN 1 Blitar dapat ditingkatkan melalui penerapan model Discovery Learning.

\section{SARAN}

Dari hasil penelitian ini kami sarankan : (1) bagi Peneliti, hasil penelitian ini dapat dijadikan sebagai masukan untuk meningkatkan proses pembelajaran kimia di kelas pada masa mendatang, khususnya untuk materi sel elektrokimia, (2) Setiap siswa menjadi lebih aktif dalam proses pembelajaran baik saat melaksanakan percobaan, kerja kelompok, membuat laporan, dan diskusi kelas, sehingga mampu menemukan sendiri konsep-konsep yang dipelajari dan hasil belajar meningkat, (3) bagi guru atau peneliti lain, dapat dijadikan acuan dalam melakukan penelitian sejenis, atau yang akan mencoba menerapkan model Discovery Learning di kelasnya. Sehingga mereka bisa mempersiapkan lebih dulu semua instrumen yang dibutuhkan dengan baik, (4) Bagi sekolah, hasil penelitian ini dapat dijadikan acuan dalam membuat kebijakan tentang peningkatan kualitas sekolah, seperti penyediaan sarana praktek untuk siswa, dan pengembangan keprofesian berkelanjutan bagi guru. 
JURNAL PENDIDIKAN: Riset dan Konseptual,

Vol. 3 No. 2, April 2019 www.journal.unublitar.ac.id/ip E-ISSN: 2598-2877

P-ISSN: 2598-5175

\section{DAFTAR RUJUKAN}

Akbar, S. 2010.Penelitian Tindakan Kelas Filosofi, Metodologi \& Implementasi.Yoyakarta: Cipta Media Aksara.

Arends, R. Learning To Teach. Terjemahan oleh Helly Prajitno Soetjipto. 2004. Yogyakarta: Pustaka Pelajar.

Kemendikbud. 2014. Materi Pelatihan Guru Implementasi Kurikulum 2013 Tahun Ajaran 2014/2015. Jakarta: Badan Pengembangan Sumber Daya Manusia Pendidikan dan Kebudayaan dan Penjaminan Mutu Pendidikan.

Kemendikbud. 2017. Panduan Penilaian Hasil Belajar pada Sekolah Menengah Kejuruan. Jakarta: Dirjen Dikdasmen.

Wijayati, E. 2016. Penerapan Metode Discovery Terpimpin untuk Meningkatkan Motivasi dan Hasil Belajar Senyawa Hidrokarbon. Jurnal Hasil Penelitian. Surabaya: Media Jawa Timur. 